Brazilian Journal of Animal Science ISSN 1806-9290

www.rbz.org.br

Brasileira de Zootecnia

\author{
*Corresponding author: \\ manumfischer@hotmail.com \\ Received: May 11, 2018 \\ Accepted: August 23, 2018 \\ How to cite: Fischer, M. M.; Moraes, M. L.; \\ Marcolla, C. S. and Kessler, A. M. 2019. Increased \\ urinary losses in piglets fed diets containing \\ high levels of glycerin. Revista Brasileira de \\ Zootecnia 48:e20180039. \\ https://doi.org/10.1590/rbz4820180039
}

Copyright: This is an open access article distributed under the terms of the

Creative Commons Attribution License (http://creativecommons.org/licenses/by/4.0/), which permits unrestricted use, distribution, and reproduction in any medium, provided the original work is properly cited.

\section{Increased urinary losses in piglets fed diets containing high levels of glycerin}

\author{
Manuela Marques Fischer ${ }^{1 *}$ (iD), Mariana Lemos de Moraes $^{1}$ (iD), Camila \\ Schultz Marcolla ${ }^{2}$ (iD), Alexandre de Mello Kessler ${ }^{1}$ (iD \\ ${ }^{1}$ Universidade Federal do Rio Grande do Sul, Programa de Pós-graduação em Zootecnia, \\ Porto Alegre, RS, Brasil. \\ ${ }^{2}$ University of Alberta, Department of Agricultural, Life and Environmental Sciences, \\ Edmonton, Alberta, Canada.
}

\begin{abstract}
This study evaluated the nutritional value of glycerin added to diets of weaned piglets and its effects on animal performance and urinary losses. Weaned piglets were individually housed in metabolic cages and fed diets in which a basal diet containing lactose (Gly0) was replaced by 50 (Gly50), 100 (Gly100), or $150 \mathrm{~g} \mathrm{~kg}^{-1}$ (Gly150) of glycerin; or a diet in which $100 \mathrm{~g} \mathrm{~kg}^{-1}$ of the lactose in the basal diet was replaced by glycerin (Gly100Lac0). Diets were offered for two periods of 12 days (phase I and phase II). Performance, nutrient digestibility, nitrogen retention (NR), and urinary production were measured. Digestible (DE) and metabolizable energy (ME) of glycerin were calculated using substitution method and compared to iso-nutritional diets formulated with or without glycerin. No significant differences on average daily gain, average daily feed intake, and feed conversion ratio were found. Glycerin inclusion caused a linear increase in urinary production. Piglets fed Gly100Lac0 diet had higher urinary production, compared with piglets fed Gly0. Glycerin had no significant effects on total tract apparent digestibility (TTAD) coefficients of dry matter (DM), crude protein, and gross energy (GE). Also, no significant effects were found in total tract apparent metabolizability (TTAM) coefficient of GE, NR coefficient, DE, ME, and fecal GE losses. Urinary production and GE in urine increased linearly and quadratically, respectively, with increased levels of glycerin in diets. The Gly100Lac0 diet resulted in lower DM TTAD and GE TTAM and higher GE losses in urine and feces compared with Gly0. The nutritional value of glycerin allows its inclusion at up to $100 \mathrm{~g} \mathrm{~kg}^{-1}$ in diets of weaned piglets without impairing animal performance and metabolism. Also, glycerin can replace $100 \mathrm{~g} \mathrm{~kg}^{-1}$ of lactose without impairing performance.
\end{abstract}

Key Words: energy metabolism, lactose, performance, urinary excretion

\title{
Introduction
}

Brazil figures as the second biggest biodiesel producer in the world (Sawin et al., 2016), with an annual production estimated at 3.87 billion L (USDA, 2016). Crude glycerin is the main byproduct of biodiesel production, and its major component is glycerol, which has been evaluated as a feed ingredient for swine diets. Adding up to 80 and $50 \mathrm{~g} \mathrm{~kg}^{-1}$ glycerol to nursery diets can potentially replace wheat (Zijlstra et al., 2008), lactose, and corn (Groesbeck et al., 2008; Shields et al., 2011), with positive effects on performance. Reported glycerol digestible (DE) and metabolizable energy (ME) for growing pigs are $3,344 \pm 8$ and 3,207 $\pm 10 \mathrm{kcal} \mathrm{kg}^{-1}$, respectively (Lammers et al., 2008). For nursery pigs, no differences on ileal digestibility of dry matter (DM) and crude protein (CP) were observed for diets in which sweet milk 
whey was substituted for 90 and $180 \mathrm{~g} \mathrm{~kg}^{-1}$ crude glycerin, respectively, indicating that the nutritional content of this feed ingredient is well utilized by young pigs (Oliveira et al., 2014). However, glycerin intake can increase urine output and urinary energy losses (Lammers et al., 2008; Mendoza et al., 2010). The present study aimed to determine nutritional value of glycerin added to diets of weaned piglets and its effects on performance and urinary losses.

\section{Material and Methods}

The experimental protocol followed the ethical principles in animal research (CONCEA, 2016) and was conducted according to the institutional committee on animal use (case no. 22583).

Thirty castrated male piglets (Agroceres PIC), weaned between 21 to 24 days of age and weighing an average $6.3 \pm 0.68 \mathrm{~kg}$, were individually housed in metabolic cages $(0.5 \times 0.8 \mathrm{~m})$ containing two dry feeders and a nipple drinker. Cages were in a temperature-controlled room, and temperature was kept within the thermoneutral zone throughout the trial $\left(27-30{ }^{\circ} \mathrm{C}\right.$ and $60-80 \%$ relative humidity).

Two basal diets were offered during the trial: phase I diet, from 1 to 12 days post weaning, and phase II diet, from 13 to 24 days post weaning. The trial was divided in a five-day adaptation period, followed by a seven-day sample collection period (phase I diet) and a 12-day sample collection period (phase II diet), summing 19 days of sample collection. Using this design, animal performance was measured in two phases, but metabolism responses were measured throughout the two phases.

Piglets were randomly assigned to one of five dietary treatments: a basal diet formulated to meet the nutritional requirements of weanling piglets (NRC, 2012) was used as the control (Gly0); the other four diets were formulated as follows: a diet containing $950 \mathrm{~g} \mathrm{~kg}^{-1}$ of the control diet and $50 \mathrm{~g} \mathrm{~kg}^{-1}$ glycerin (Gly50); a diet containing $900 \mathrm{~g} \mathrm{~kg}^{-1}$ of the control diet and $100 \mathrm{~g} \mathrm{~kg}^{-1}$ glycerin (Gly100); a diet containing $850 \mathrm{~g} \mathrm{~kg}^{-1}$ of the control diet and $150 \mathrm{~g} \mathrm{~kg}^{-1}$ glycerin (Gly150); and a diet containing the same nutritional content of the control diet in which $100 \mathrm{~g} \mathrm{~kg}^{-1}$ glycerin was added at the expense of lactose (Gly100Lac0) (Table 1). Feed and water were provided ad libitum throughout the experiment.

During sample collection periods, total feces produced by each piglet were collected once a day and stored at $-15{ }^{\circ} \mathrm{C}$. Urine was collected into plastic buckets containing $5 \mathrm{~mL}$ of sulfuric acid $\left(\mathrm{H}_{2} \mathrm{SO}_{4}\right)$. The buckets were weighted daily, and $100 \mathrm{~mL} \mathrm{~L}^{-1}$ of urine volume produced were collected and stored at $-15{ }^{\circ} \mathrm{C}$. At the end of the experiment, fecal and urinary samples from each piglet were thawed, homogenized, and a 100-mL urine and a 400-g feces subsamples were used for further analysis. Fecal subsamples were dried at $60^{\circ} \mathrm{C}$ for $72 \mathrm{~h}$, weighed, and ground through a $2-\mathrm{mm}$ screen.

Dry matter and $\mathrm{N}$ content of diets and feces were analyzed according to AOAC (2007) (method 930.15 and method 984.13, respectively). Gross energy of glycerin, diets, feces, and urine were determined using isoperibol bomb calorimeter (C2000, IKAWerke GmbH \& Co. KG, Staufen, Germany). Nitrogen in urine was determined according to AOAC (2007) (method 984.13).

Animal performance; total tract apparent digestibility (TTAD) coefficients of DM, CP, and gross energy (GE); total tract apparent metabolizability (TTAM) coefficient of GE, nitrogen retention (NR) coefficient, $\mathrm{DE}\left(\mathrm{kcal} \mathrm{kg}^{-1} \mathrm{DM}\right), \mathrm{ME}\left(\mathrm{kcal} \mathrm{kg}^{-1} \mathrm{DM}\right)$, urine output, and fecal and urine energy content were determined according to Sakomura and Rostagno (2007).

The DE and ME values were estimated using the substitution method: using the Gly0 diet as the reference diet, and the diets containing glycerin included at the expense of the control diet (Gly50, Gly100, Gly150) as the substitution diets. Calculations were performed according to equations proposed by Campbell et al. (1983).

The experimental design was completely randomized, with five treatments, six replicates, and a total of 30 experimental units. Results were analyzed by ANOVA using GLM procedure of SAS (Statistical Analysis System, version 9.2.). With significant differences identified by F-test $(\mathrm{P}<0.05)$, polynomial regression was performed using glycerol level $\left(\mathrm{g} \mathrm{kg}^{-1}\right)$ as independent variable. To test the effect of substitution of lactose with glycerol, treatments Gly0 and Gly100Lac0 were compared using paired $t$ test, and the probability level of $\mathrm{P}<0.05$ was considered as statistically significant.

R. Bras. Zootec., 48:e20180039, 2019 
Table 1 - Composition ( $\mathrm{g} \mathrm{kg}^{-1}$ as fed) and calculated nutritional composition of diets

\begin{tabular}{|c|c|c|c|c|}
\hline \multirow{3}{*}{ Ingredient } & \multicolumn{4}{|c|}{ Diet $^{2}$} \\
\hline & \multicolumn{2}{|c|}{ Phase I } & \multicolumn{2}{|c|}{ Phase II } \\
\hline & Gly0 & Gly100Lac0 & Gly0 & Gly100Lac0 \\
\hline Corn & 470.5 & 470.5 & 554.3 & 554.3 \\
\hline Soybean meal & 126.7 & 126.7 & 151.2 & 151.2 \\
\hline Lactose & 100.0 & - & 100.0 & - \\
\hline Glycerin $^{3}$ & - & 100.0 & - & 100.0 \\
\hline Milk powder & 107.9 & 107.9 & - & - \\
\hline Plasma meal & 50.00 & 50.00 & 50.00 & 50.00 \\
\hline Gluten corn 60 & 50.00 & 50.00 & 50.00 & 50.00 \\
\hline Sugar & 30.00 & 30.00 & 30.00 & 30.00 \\
\hline Soybean oil & 20.00 & 20.00 & 20.00 & 20.00 \\
\hline Dicalcium phosphate & 16.60 & 16.60 & 16.80 & 16.80 \\
\hline Calcium carbonate & 5.80 & 5.80 & 9.60 & 9.60 \\
\hline L-lysine $\mathrm{HCl}$ & 5.10 & 5.10 & 4.90 & 4.90 \\
\hline DL-methionine & 2.30 & 2.30 & 1.90 & 1.90 \\
\hline L-threonine & 2.30 & 2.30 & 1.60 & 1.60 \\
\hline L-tryptophan & 0.20 & 0.20 & 0.20 & 0.20 \\
\hline Choline & 1.30 & 1.30 & 1.30 & 1.30 \\
\hline Salt & 2.16 & 2.16 & 2.16 & 2.16 \\
\hline Acidifier & 4.00 & 4.00 & 3.00 & 3.00 \\
\hline Antioxidant & 0.20 & 0.20 & 0.20 & 0.20 \\
\hline Mineral premix ${ }^{4}$ & 0.97 & 0.97 & 0.97 & 0.97 \\
\hline Vitamin premix ${ }^{5}$ & 0.50 & 0.50 & 0.50 & 0.50 \\
\hline Zinc oxide & 2.10 & 2.10 & - & - \\
\hline Copper sulphate & 0.37 & 0.37 & 0.37 & 0.37 \\
\hline Antibiotic $^{6}$ & 1.00 & 1.00 & 1.00 & 1.00 \\
\hline \multicolumn{5}{|c|}{ Calculated nutritional composition ( $\mathrm{g} \mathrm{kg}^{-1}$ as fed) } \\
\hline $\mathrm{CP}$ & 200.0 & 200.0 & 190.0 & 190.0 \\
\hline Crude fat & 63.90 & 63.90 & 43.4 & 43.4 \\
\hline Lactose & 140.0 & 40.00 & 100.0 & 0 \\
\hline $\mathrm{Ca}$ & 7.00 & 7.00 & 7.50 & 7.50 \\
\hline Available P & 5.00 & 5.00 & 4.40 & 4.40 \\
\hline Sodium & 3.00 & 4.5 & 2.50 & 4.00 \\
\hline SID lysine & 14.08 & 14.08 & 12.37 & 12.37 \\
\hline SID methionine & 5.46 & 5.46 & 4.72 & 4.72 \\
\hline SID met + cys & 8.77 & 8.77 & 7.94 & 7.94 \\
\hline SID tryptophan & 2.28 & 2.28 & 2.08 & 2.08 \\
\hline SID threonine & 9.46 & 9.46 & 8.29 & 8.29 \\
\hline
\end{tabular}

SID threonine

gy content in lactose and glycerin)

\begin{tabular}{lllll}
\hline ME & 3570 & 3570 & 3390 & 3390
\end{tabular}

SID - standardized ileal digestible amino acid; ME - metabolizable energy.

1 Values calculated according to Rostagno et al. (2011)

2 Gly0: basal diet used as the control diet; Gly100Lac0: basal diet in which $100 \mathrm{~g} \mathrm{~kg}^{-1}$ of lactose was replaced by glycerin.

${ }^{3}$ Glycerol, $821.4 \mathrm{~g} \mathrm{~kg}^{-1}$; water, $115.4 \mathrm{~g} \mathrm{~kg}^{-1}$; ash 60.7, $\mathrm{g} \mathrm{kg}^{-1}$; sodium, $15.0 \mathrm{~g} \mathrm{~kg}^{-1}$; and methanol, $0.05 \mathrm{~g} \mathrm{~kg}^{-1}$ (Granol Indústria Comércio e Exportação S/A).

${ }^{4}$ Provided per kilogram of diet: Fe, $77.6 \mathrm{mg}$; Cu, $11.6 \mathrm{mg}$; Mn, $67.9 \mathrm{mg}$; Zn, $97.0 \mathrm{mg}$; I, $0.97 \mathrm{mg}$; Se, $0.31 \mathrm{mg}$.

${ }^{5}$ Provided per kilogram of diet: vitamin A, 11,250 UI; vitamin D3, 2250 UI; vitamin E, 22.5 UI; vitamin K3, 2.0 mg; vitamin B1, $1.75 \mathrm{mg}$; vitamin B2, $5.0 \mathrm{mg}$; vitamin B6, $1.75 \mathrm{mg}$; vitamin B12, $22.5 \mathrm{mcg}$; niacin, $37.5 \mathrm{mg}$; pantothenic acid, $20.0 \mathrm{mg}$; folic acid, $0.5 \mathrm{mg}$; biotin, $0.125 \mathrm{mg}$.

${ }^{6}$ Halquinol $120 \mathrm{~g} \mathrm{~kg}^{-1}$. 


\section{Results}

No significant differences $(\mathrm{P}>0.05)$ on average daily gain (ADG), average daily feed intake (ADFI), and feed conversion ratio were observed among treatments (Table 2). A linear effect of glycerin on urinary production was observed in Phase I $\left(\mathrm{P}<0.0001 ; \mathrm{R}^{2}=0.656\right)$ and Phase II $\left(\mathrm{P}<0.0001 ; \mathrm{R}^{2}=0.431\right)$ (Table 2). Piglets fed the Gly100Lac0 diet showed an increase in urinary production compared with piglets fed Gly0, during Phase I $(\mathrm{P}<0.001)$ and Phase II $(\mathrm{P}<0.002)$. There were no significant effects $(\mathrm{P}>0.05)$ on DM TTAD, CP TTAD, GE TTAD, GE TTAM, and NR coefficients when all glycerin levels were compared. However, in the paired test analysis, Gly100Lac0 resulted in lower DM TTAD $(\mathrm{P}=0.030)$ and GE TTAM $(\mathrm{P}=0.019)$ compared with Gly0. In addition, Gly100Lac0 increased GE content in feces $(\mathrm{P}=0.043)$ and urine $(\mathrm{P}=0.001)$ compared with Gly0.

No effects of glycerin inclusion levels on DE, ME, and GE losses in feces (Table 3) were observed $(P>0.05)$; however, urinary gross energy increased quadratically with increased levels of glycerin inclusion $\left(\mathrm{P}=0.001 ; \mathrm{R}^{2}=0.870\right)$. In the paired $t$ test analysis, piglets fed Gly100Lac0 had higher GE losses in feces $(\mathrm{P}=0.043)$ and urine $(\mathrm{P}=0.001)$ compared with piglets fed Gly0.

Estimated DE and ME values for glycerin based on the substitution method calculation were, respectively: 3528 and $3378 \mathrm{kcal} \mathrm{kg}^{-1} \mathrm{DM}$ in diets containing $50 \mathrm{~g} \mathrm{~kg}^{-1}$ glycerin; 4118 and $3469 \mathrm{kcal} \mathrm{kg}^{-1} \mathrm{DM}$ in diets containing $100 \mathrm{~g} \mathrm{~kg}^{-1}$ glycerin; and 3918 and $2869 \mathrm{kcal} \mathrm{kg}^{-1} \mathrm{DM}$ in diets containing $150 \mathrm{~g} \mathrm{~kg}^{-1}$ glycerin (Table 4).

Table 2 - Performance and urinary production in phase I, phase II, and total period

\begin{tabular}{|c|c|c|c|c|c|c|c|c|}
\hline \multirow{2}{*}{ Variable } & \multicolumn{5}{|c|}{$\operatorname{Diet}^{1}$} & \multirow{2}{*}{$\mathrm{SE}$} & \multirow{2}{*}{ P-value } & \multirow{2}{*}{$\begin{array}{c}\text { t test }(\mathrm{P}<) \\
\text { Gly0 } \times \text { Gly100Lac0 }\end{array}$} \\
\hline & Gly0 & Gly50 & Gly100 & Gly150 & Gly100Lac0 & & & \\
\hline \multicolumn{9}{|c|}{ Phase I (1 to 12 days post-weaning) } \\
\hline ADG (kg/day) & 0.464 & 0.458 & 0.437 & 0.465 & 0.485 & 0.048 & 0.792 & 0.763 \\
\hline ADFI (kg/day) & 0.506 & 0.478 & 0.522 & 0.491 & 0.577 & 0.090 & 0.696 & 0.450 \\
\hline FCR & 1.104 & 1.040 & 1.220 & 1.044 & 1.198 & 0.201 & 0.677 & 0.576 \\
\hline Initial BW (kg) & 6.42 & 6.39 & 6.31 & 6.32 & 6.3 & 0.565 & 0.997 & 0.765 \\
\hline Final BW (kg) & 11.99 & 11.89 & 11.55 & 11.90 & 12.12 & 1.071 & 0.962 & 0.955 \\
\hline
\end{tabular}

Phase II (12 to 24 days post-weaning)

$\begin{array}{lcccccccc}\text { ADG (kg/day) } & 0.716 & 0.778 & 0.717 & 0.734 & 0.765 & 0.081 & 0.743 & 0.477 \\ \text { ADFI (kg/day) } & 0.952 & 1.028 & 0.960 & 1.039 & 0.955 & 0.085 & 0.514 & 0.839 \\ \text { FCR } & 1.332 & 1.322 & 1.359 & 1.423 & 1.263 & 0.092 & 0.300 & 0.415 \\ \text { Initial BW (kg) } & 11.99 & 11.89 & 11.55 & 11.90 & 12.12 & 1.071 & 0.962 & 0.955 \\ \text { Final BW (kg) } & 20.58 & 21.22 & 20.16 & 20.71 & 21.3 & 2.023 & 0.931 & 0.690 \\ & & & & & & & & \\ \text { Total period (1 to 24 days post-weaning) } & & & & & & \\ \text { ADG (kg/day) } & 0.583 & 0.608 & 0.568 & 0.591 & 0.617 & 0.049 & 0.714 & 0.520 \\ \text { ADFI (kg/day) } & 0.716 & 0.737 & 0.728 & 0.749 & 0.754 & 0.074 & 0.960 & 0.622 \\ \text { FCR } & 1.230 & 1.208 & 1.295 & 1.264 & 1.237 & 0.111 & 0.877 & 0.949 \\ \text { Initial BW (kg) } & 6.42 & 6.39 & 6.31 & 6.32 & 6.3 & 0.565 & 0.997 & 0.765 \\ \text { Final BW (kg) } & 20.58 & 21.22 & 20.16 & 20.71 & 21.3 & 2.023 & 0.931 & 0.690 \\ & & & & & & & & \\ \text { Urinary production } & & & & & & & & \\ \text { Phase I (g/day) } & 301.8 & 443.2 & 734.2 & 1143.8 & 633.2 & 129.9 & 0.001 & 0.001 \\ \text { Phase II (g/day) } & 1120.2 & 1332.1 & 1601.4 & 2511.5 & 1881.8 & 400.5 & 0.002 & 0.023\end{array}$

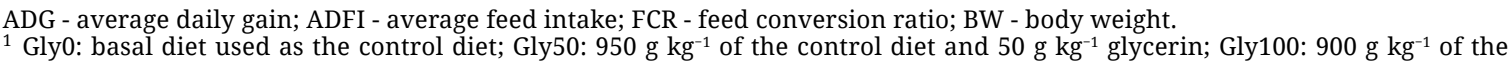
control diet and $100 \mathrm{~g} \mathrm{~kg}^{-1}$ glycerin; Gly150: $850 \mathrm{~g} \mathrm{~kg}^{-1}$ of the control diet and $150 \mathrm{~g} \mathrm{~kg}^{-1}$ glycerin; Gly100Lac0: control diet in which $100 \mathrm{~g} \mathrm{~kg}^{-1}$ of lactose was replaced by glycerin.

${ }^{2}$ Linear effect of glycerin level: $\mathrm{Y}=232.6+5.163 \mathrm{X} ; \mathrm{P}<0.0001 ; \mathrm{R}^{2}=0.656$.

3 Linear effect of glycerin level: $\mathrm{Y}=1001.5+8.678 \mathrm{X} ; \mathrm{P}<0.0001 ; \mathrm{R}^{2}=0.431$. 
Table 3 - Apparent digestibility coefficients of nutrients, metabolizability coefficient of gross energy, nitrogen retention coefficient, and energy content of diets, feces, and urine

\begin{tabular}{|c|c|c|c|c|c|c|c|c|}
\hline \multirow{2}{*}{ Variable } & \multicolumn{5}{|c|}{ Diet $^{1}$} & \multirow{2}{*}{$\mathrm{SE}$} & \multirow{2}{*}{ P-value } & \multirow{2}{*}{$\frac{\text { t test }(\mathrm{P}<)}{\text { Gly0 } \times \text { Gly100Lac0 }}$} \\
\hline & Gly0 & Gly50 & Gly100 & Gly150 & Gly100Lac0 & & & \\
\hline DM TTAD $\left(\mathrm{g} \mathrm{g}^{-1}\right)$ & 0.897 & 0.878 & 0.900 & 0.898 & 0.867 & 0.015 & 0.066 & 0.030 \\
\hline CP TTAD $\left(\mathrm{g} \mathrm{g}^{-1}\right)$ & 0.862 & 0.836 & 0.864 & 0.854 & 0.833 & 0.024 & 0.311 & 0.104 \\
\hline GE TTAD ( $\left.\mathrm{g} \mathrm{g}^{-1}\right)$ & 0.894 & 0.879 & 0.898 & 0.897 & 0.870 & 0.016 & 0.113 & 0.085 \\
\hline GE TTAM $\left(\mathrm{g} \mathrm{g}^{-1}\right)$ & 0.880 & 0.863 & 0.871 & 0.842 & 0.845 & 0.017 & 0.053 & 0.019 \\
\hline $\mathrm{NR}\left(\mathrm{g} \mathrm{g}^{-1}\right)$ & 0.789 & 0.756 & 0.780 & 0.766 & 0.751 & 0.025 & 0.315 & 0.115 \\
\hline $\mathrm{DE}\left(\mathrm{kcal} \mathrm{kg}^{-1} \mathrm{DM}\right)$ & 4148 & 4127 & 4260 & 4255 & 4206 & 74.0 & 0.096 & 0.345 \\
\hline ME (kcal kg-1 DM) & 4082 & 4054 & 4132 & 3997 & 4084 & 81.0 & 0.452 & 0.981 \\
\hline GE feces $\left(\mathrm{kcal}^{-1} \mathrm{~kg}\right.$ DM) & 491.7 & 570.1 & 481.9 & 489.7 & 626.7 & 74.0 & 0.068 & 0.043 \\
\hline GE urine $\left(\mathrm{kcal}^{-1} \mathrm{~kg} \mathrm{DM}\right)^{2}$ & 65.7 & 72.6 & 127.9 & 271.0 & 122.4 & 18.5 & 0.001 & 0.001 \\
\hline
\end{tabular}

DM TTAD - total tract apparent digestibility coefficient of dry matter; CP TTAD - total tract apparent digestibility coefficient of crude protein; GE TTAD - total tract apparent digestibility coefficient of gross energy; GE TTAM - total tract apparent metabolizability coefficient of gross energy; NR - nitrogen retention coefficient; DE - digestible energy; ME - metabolizable energy; GE - gross energy; DM - dry matter.

${ }^{1}$ Gly0: basal diet used as the control diet; Gly50: $950 \mathrm{~g} \mathrm{~kg}^{-1}$ of the control diet and $50 \mathrm{~g} \mathrm{~kg}^{-1} \mathrm{glycerin}$ Gly100: $900 \mathrm{~g}$ kg-1 of the control diet and $100 \mathrm{~g} \mathrm{~kg}^{-1}$ glycerin; Gly150: $850 \mathrm{~g} \mathrm{~kg}^{-1}$ of the control diet and $150 \mathrm{~g} \mathrm{~kg}^{-1}$ glycerin; Gly100Lac0: control diet in which $100 \mathrm{~g} \mathrm{~kg}^{-1}$ of lactose was replaced by glycerin.

${ }^{2}$ Quadratic effect of glycerin level: $\mathrm{Y}=68.31-0.8019 \mathrm{X}+0.0141 \mathrm{X}^{2} ; \mathrm{P}<0.0001 ; \mathrm{R}^{2}=0.870$

Table 4 - Estimated digestible (DE) and metabolizable energy (ME) of glycerin added at expense of the control diet, calculated using the substitution method

\begin{tabular}{lcc}
\hline Glycerin level $\left(\mathrm{g} \mathrm{kg}^{-1}\right)$ & DE estimated $\left(\mathrm{kcal} \mathrm{kg}^{-1} \mathrm{DM}\right)$ & ME estimated $\left(\mathrm{kcal} \mathrm{kg}^{-1} \mathrm{DM}\right)$ \\
\hline 50 & 3528 & 3378 \\
100 & 4118 & 3469 \\
150 & 3918 & 2869 \\
$\mathrm{SE}$ & 604 & 774 \\
P-value & 0.546 & 0.651 \\
Average & $3855 \pm 219$ & $3239 \pm 279$ \\
\hline
\end{tabular}

SE - standard error; DM - dry matter.

\section{Discussion}

The ADG and ADFI observed in this study were higher than the estimated expected ADG and ADFI for piglets at a relatively stress-free environment (NRC, 2012), indicating that the nutrient dilution resultant from glycerin inclusion did not impair performance. Other studies also reported no effects on performance in nursery piglets fed diets containing 120 and $140 \mathrm{~g} \mathrm{~kg}^{-1}$ glycerin (Diaz-Huepa et al., 2015; Gallego et al., 2016), whereas several authors found improved performance results in nursery pigs fed up to $100 \mathrm{~g} \mathrm{~kg}^{-1}$ crude glycerol (Groesbeck et al., 2008; Zijlstra et al., 2008; Shields et al., 2011; Rocha et al., 2016). The replacement of $100 \mathrm{~g} \mathrm{~kg}^{-1}$ of lactose with glycerin in diets of weaned piglets resulted in lower DM TTAD and GE TTAM coefficients and higher GE losses in urine and feces; however, piglet performance was not negatively affected, indicating that glycerin may be a viable alternative to replace up to $100 \mathrm{~g} \mathrm{~kg}^{-1}$ of lactose in diets of weaned piglets.

The inclusion levels tested had no negative effects on digestibility and metabolizability of the diets; however, increases in urine output and energy excretion were observed as glycerin inclusion levels increased. The results indicated that glycerin levels higher than $100 \mathrm{~g} \mathrm{~kg}^{-1}$ could limit energy utilization of the diet and agree with Lammers et al. (2008), who reported that 11-kg pigs may not be able to metabolize diets containing more than $100 \mathrm{~g} \mathrm{~kg}^{-1}$ of crude glycerol. Similarly, Oliveira et al. (2014) reported that inclusion of 90 and $180 \mathrm{~g} \mathrm{~kg}^{-1}$ of glycerin to nursery diets increased 
urinary glycerol excretion but had no effect on apparent ileal digestibility of the diets. It is suggested that the metabolic pathways of glycerol utilization may become saturated when pigs are fed high levels of glycerin, and the higher urinary excretion of glycerol may explain the higher gross energy content of urine. The glycerol present in the urine may also exert a diuretic effect, which may increase water intake and urine production (Mendoza et al., 2010). Additionally, the higher urinary production observed in piglets fed glycerin in the present study may be a consequence of the higher sodium content of those diets due to sodium present in glycerol that was not considered during diet formulation. Diets with high sodium content can result in increased water intake and urinary production, but will not necessarily impair pig performance, provided that animals have ad libitum access to non-saline water (Chittavong et al., 2013).

According to Campbell et al. (1983), the substitution method estimates can be impaired when using lower levels of inclusion, due to an amplification of analytical variability. Thus, at $50 \mathrm{~g} \mathrm{~kg}^{-1}$ inclusion level, the variability is multiplied by 20 , reducing the reliability of the results. As increased gross energy of urine at $150 \mathrm{~g} \mathrm{~kg}^{-1}$ inclusion leads to a numerical reduction of glycerin estimated ME content, we considered the DE and ME estimates obtained at $100 \mathrm{~g} \mathrm{~kg}^{-1}$ inclusion, which were 4118 and $3469 \mathrm{kcal} \mathrm{kg}^{-1} \mathrm{DM}$. The glycerin DE and ME values estimated by the substitution method were intermediate in relation to those reported in the literature for weaned piglets. Using regression analysis, Carvalho et al. (2012) reported estimated DE and ME values of glycerin as 5070 and $4556 \mathrm{kcal} \mathrm{kg}^{-1}$, respectively; Lammers et al. (2008) reported $4401 \mathrm{kcal} \mathrm{kg}^{-1} \mathrm{DE}$ and $3463 \mathrm{kcal} \mathrm{kg}^{-1} \mathrm{ME}$ for glycerol; whereas Diaz-Huepa et al. (2015) reported $3534 \mathrm{kcal} \mathrm{kg}^{-1} \mathrm{DE}$ and $3279 \mathrm{kcal} \mathrm{kg}^{-1} \mathrm{ME}$ for glycerin. The glycerin origin and purity can affect its composition and nutritional value (Carvalho et al., 2013), which may explain the variability across studies. Further investigation of glycerol excretion in the urine of pigs fed glycerin is needed, as it may impact ME content of this ingredient, and the increased urine output can also increase environmental impact of swine production.

\section{Conclusions}

The nutritional value of glycerin allows its inclusion at up to $100 \mathrm{~g} \mathrm{~kg}^{-1}$ in diets of weaned piglets without impairing animal performance and metabolism. Considering animal performance, glycerin can replace $100 \mathrm{~g} \mathrm{~kg}^{-1}$ of lactose in diets of weaned piglets, but this substitution causes lower energy metabolizability and higher urinary production and energy losses.

\section{Acknowledgments}

The authors acknowledge the Brazilian governmental research support institution Conselho Nacional de Desenvolvimento Científico e Tecnológico (CNPq), for the doctoral scholarship granted to the first author.

\section{References}

AOAC - Association of Official Analytical Chemistry. 2007. Official methods of analysis of AOAC International. 18th ed. AOAC International, Gaithersburg, MD.

Campbell, G. L.; Campbell, L. D. and Blair, R. 1983. Calculation of metabolizable energy for ingredients incorporated at low levels into a reference diet. Poultry Science 62:705-707. https://doi.org/10.3382/ps.0620705

Carvalho, P. L. O.; Moreira, I.; Martins, E. N.; Piano, L. M.; Toleto, J. B. and Costa Filho, C. L. 2012. Crude glycerine in diets for piglets. Revista Brasileira de Zootecnia 41:1654-1661. https://doi.org/10.1590/S1516-35982012000700014

Carvalho, P. L. O.; Moreira, I.; Scapinello, C.; Piano, L. M.; Gallego, A. G. and Moresco, G. 2013. Crude glycerine in growing and finishing pigs feeding. Semina Ciências Agrárias 34:1399-1410.

Chittavong, M.; Jansson, A. and Lindberg, J. E. 2013. Effects of high dietary sodium chloride content on performance and sodium and potassium balance in growing pigs. Tropical Animal Health and Production 45:1477-1483. https://doi. org/10.1007/s11250-013-0385-4 
CONCEA - Conselho Nacional de Controle de Experimentação Animal. 2016. Diretriz brasileira para o cuidado e a utilização de animais em atividades de ensino ou de pesquisa científica. Available at: <http://mct.gov.br/upd_blob/0238/238684. pdf $>$. Accessed on: Dec. 12, 2017.

Diaz-Huepa, L. M.; Moreira, I.; Pozza, P. C.; Carvalho, P. L. O.; Pasquetti, T. J. and Sierra, L. M. P. 2015. Neutralized semipurified glycerin in pre-starting piglet feeding (6 to $15 \mathrm{~kg}$ ). Semina Ciências Agrárias 36:2839-2848.

Gallego, A. G.; Moreira, I.; Carvalho, P. L. O.; Perondi, D.; Pasquetti, T. J. and Gonçalves, L. M. P. 2016. Neutral semipurified glycerin in growing and finishing pigs feeding. Italian Journal of Animal Science 15:87-93. https://doi org/10.1080/1828051X.2016.1148560

Groesbeck, C. N.; McKinney, L. J.; DeRouchey, J. M.; Tokach, M. D.; Goodband, R. D.; Dritz, S. S.; Nelssen, J. L.; Duttlinger, A. W.; Fahrenholz, A. C. and Behnke, K. C. 2008. Effect of crude glycerol on pellet mill production and nursery pig growth performance. Journal of Animal Science 86:2228-2236. https://doi.org/10.2527/jas.2008-0880

Lammers, P. J.; Kerr, B. J.; Weber, T. E.; Dozier, W. A.; Kidd, M. T.; Bregendahl, K. and Honeyman, M. S. 2008. Digestible and metabolizable energy of crude glycerol for growing pigs. Journal of Animal Science 86:602-608. https://doi.org/10.2527/ jas.2007-0453

Mendoza, O. F.; Ellis, M.; McKeith, F. K. and Gaines, A. M. 2010. Metabolizable energy content of refined glycerin and its effects on growth performance and carcass and pork quality characteristics of finishing pigs. Journal of Animal Science 88:3887-3895. https://doi.org/10.2527/jas.2010-2873

NRC - National Research Council. 2012. Nutrient requirements of swine. 11th rev. ed. The National Academies Press, Washington, DC.

Oliveira, L.; Madrid, J.; Ramis, G.; Martínez, S.; Orengo, J.; Villodre, C.; Valera, L.; López, M. J.; Pallarés, F. J.; Quereda, J. J.; Mendonça, L. and Hernández, F. 2014. Adding crude glycerin to nursery pig diet: Effect on nutrient digestibility, metabolic status, intestinal morphology and intestinal cytokine expression. Livestock Science 167:227-235. https://doi. org/10.1016/j.livsci.2014.05.013

Rocha, L. O.; Silva, J. L.; Rodrigues, C. P. F.; Mascarenhas, A. G. and Nunes, R. C. 2016. Glicerina bruta nas rações para leitões na fase de creche. Ciência Animal Brasileira 17:51-59. https://doi.org/10.1590/1089-6891v17i126479

Rostagno, H. S.; Albino, L. F. T.; Donzele, J. L.; Gomes, P. C.; Oliveira, R. F.; Lopes, D. C.; Ferreira, A. S.; Barreto, S. L. T and Euclides, R. F. 2011. Tabelas brasileiras para aves e suínos: composição de alimentos e exigências nutricionais. 3.ed. UFV, Viçosa, MG.

Sakomura, N. K. and Rostagno, H. S. 2007. Métodos de pesquisa em nutrição de monogástricos. FUNEP, Jaboticabal, SP.

Sawin, J. L.; Seyboth, K. and Sverrisson, F. 2016. Renewables 2016: Global Status Report. Available at: <http://www.ren21. net/resources/publications/>. Accessed on: Dec. 12, 2017.

Shields, M. C.; van Heugten, E.; Lin, X.; Odle, J. and Stark, C. S. 2011. Evaluation of the nutritional value of glycerol for nursery pigs. Journal of Animal Science 89:2145-2153. https://doi.org/10.2527/jas.2010-3558

USDA, FAS. 2016. Biofuels annual report 2016. Brazil. 2015:26. Available at: <http://gain.fas.usda.gov/Recent GAIN Publications/Biofuels Annual_Sao Paulo AT0_Brazil_8-12-2016.pdf\%0D\%0A>. Accessed on: Dec. 12, 2017.

Zijlstra, R. T.; Menjivar, K.; Lawrence, E. and Beltranena, E. 2008. Short communication: The effect of feeding crude glycerol on growth performance and nutrient digestibility in weaned pigs. Canadian Journal of Animal Science 89:85-89. https://doi.org/10.4141/CJAS08072 